\title{
PENGATURAN KECEPATAN MOTOR AC SEBAGAI AERATOR UNTUK BUDIDAYA TAMBAK UDANG DENGAN MENGGUNAKAN SOLAR CELL
}

\author{
Sofiah $^{1}$,Yosi Apriani ${ }^{2}$ \\ Program Studi Teknik Elektro Fakultas Teknik Universitas Muhammadiyah Palembang \\ sofikeran@gmail.com,yosi_apriani@um-palembang.ac.id
}

\begin{abstract}
Abstrak-----Aerator merupakan suatu alat untuk membantu pembudidaya udang dalam mengalirkan udara atau meningkatkan nilai oksigen sehingga akan lebih banyak oksigen yang masuk ke dalam air untuk membantu pertumbuhan udang tersebut. Aerator terdiri dari beberapa komponen penunjang yaitu motor AC, akumulator, inverter, impeller dan rangka. Aerator ini dirancang menggunakan solar cell sebagai sumber energi. Pada hasil pengujian solar cell menyuplai arus 5,7 ampere dengan tegangan 17,5 volt, akumulator bekerja pada tegangan 12v/70Ah, dengan arus pengisian dari solar cell dan charger akumulator 5,7 ampere dengan waktu pengisian arus lebih kurang 12,2 jam, daya inverter maximum dihitung dengan adalah 500watt.
\end{abstract}

Kata kunci :Aerator, , akumulator, motor ac, inverter

Abstract------Aerator is a tool to help shrimp farmers to drain air or increase the value of oxygen so that more oxygen will enter the water to help grow the shrimp. Aerator consists of several supporting components namely AC motor, accumulator, inverter, impeller and frame. This aerator is designed using solar cells as an energy source. In the results of testing the solar cell supplying 5.7 amperes of current with a voltage of 17.5 volts, the accumulator works on a voltage of $12 \mathrm{v} / 70 \mathrm{Ah}$, with charging current from the solar cell and accumulator charger 5.7 amperes with a charging time of approximately 12.2 hours, maximum calculated inverter power is 500 watts.

Keywords: Aerator, accumulator, ac motor, inverter

\section{PENDAHULUAN}

Indonesia merupakan Negara kepulauan dimana luas negara Indonesia terdiri dari 17.508 pulau dengan panjang garis pantai $81.000 \mathrm{~km}$. menyatakan perairan laut yang berada dalam dalam kedaulatan negara kesatuan Republik Indonesia dari zona ekonomi ekslusif Indonesia serta laut lepas tersebut mengandung sumber daya [1].Sehingga budidaya perairan khusus nya air tawar sangat menjanjikan untuk para petani yang berkecimpung di bidang perikanan, salah satunya budidaya peternak udang air tawar [2].

Udang adalah komoditas perikanan andalan Indonesia yang menjadi komoditas ekspor. Terdapat beberapa jenis udang yang banyak dipelihara petambak di indonesia, yaitu udang wisnu, udang vaname, udang api-api, udang putih dan udang gala. Secara komersial budidaya udang di Indonesia telah dilakukan sekitar tahun 1980 kemudian pada tahun 1984 mulai dibudidayakan secara intensif yang diawali di Jawa Timur. Produksi udang terus bertambah seiring dengan meningkatnya permintaan konsumen dunia terutama dari Negara-negara Amerika Serikat, Jepang, dan Eropa Barat [2].

Untuk meningkatkan produktivitas petambak budidaya udang, salah satu faktor penting yang harus diperhatikan adalah penyediaan oksigen yang ada pada petambak udang tersebut agar udang 
yang terdapat didalamnya tidak kekurangan oksigen.Aerasi pada tambak udang merupakan yang utama bagi kehidupan petambak seperti udang, serta dasar dalam usaha pengembangan petambak udang.Salah satu permasalahan utama tambak udang adalah kondisi lingkungan yang tidak sesuai dengan kebutuhan hidup udang.

\section{TINJAUAN PUSTAKA}

\section{A. Aerator}

Aerator merupakan alat mekanis yang berfungsi untuk meningkatkan nilai oksigen kedalam permukaan air sehingga akan lebih banyak oksigen yang masuk dalam air [3]. Fungsi aerator antara lain:

Aerasi adalah penambahan udara yang mengandung oksigen ke dalam air. Aerasi dapat dilakukan dengan bantuan alat mekanik yang disebut aerator yang berfungsi sebagai berikut:

1. Memindahkan oksigen secara langsung ke dalam air.

2. Mensirkulasi atau mencampur lapisan atas air atau permukaan air dengan dasar air untuk memastikan kandungan oksigen di dalam air benar-benar merata.

3. Memindahkan air yang telah terearasi dengan cepat kearea sekelilingnya sehingga belum terearasi dapat terearasi.

4. Dengan lapisan sedimen organik di dalam kolam, akan menciptakan permukaan yang teroksidasi gas-gas dan cairan beracun seperti hidrogen sulfida dan amonia tidak dapat masuk air.

5. Sirkulasi akan mendorong berbagai macam gasberbahayanitrogenberlebihandan karbondioksida untuk lepas kedalam atmosfer.

\section{B. Prinsip Kerja Rangkaian Aerator}

Mula-mula solar cell menerima dan menyerap matahari, kemudian mengisi muatan arus dan tegangan listriknya ke akumlator 12 volt secara kontinyu. Kemudian dari akumulator arus dan tegangan akan disuplay keterminal input inverter, akan mengubah arus searah menjadi arus tengan bolak-balik sebesar 220 volt.

Selanjutnya arus dan tegangan listrik tersebut dialirkan ke alat pengatur kecepatanmotor yang bekerja sebagai alat pengatur tegangan listrik ke motor induksi 1 fasa dengan arus dan tegangan inilah, motor induksi berputar dengan kecepatan low rpm-high rpm yaitu 0-1500 rpm. Sehingga rotor motor dengan menggunakan tangkai aerator dapat difungsikan dengan kecepatan putar untuk menjadikan gelembung air dan arus alir airnya. 


\section{AKUMULATOR}

Akumulator (aki) adalah sebuah alat yang dapat menyimpan energi (umumnya energi listrik) dalam bentuk energi kimia.Contoh-contoh akumulator adalah baterai dan kapasitor.Akumulator atau aki tersusun atas pelat timbal sebagai elektrode negatif dan pelat timbal dioksida sebagai elektrode positif, dan larutan elektrolit asam sulfat. Di antara kedua elektrode, dibatasi dengan bahan isolator. Hal itu dimaksudkan, agar aki tidak bersentuhan (kalau, terjadi sentuhan menyebabkan korsleting) [4].

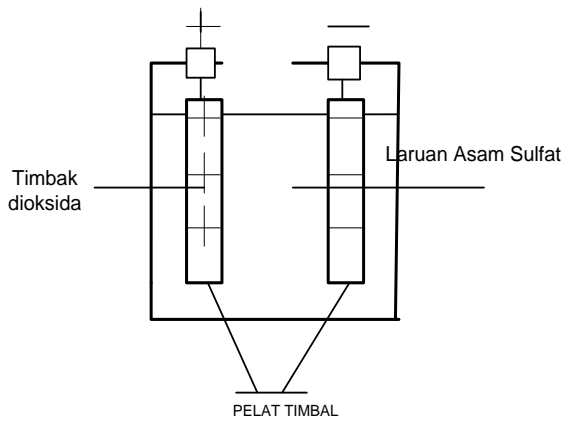

Gambar 1. Bagian-Bagian Akumulator (aki)

Prinsip kerja aki, pada saat aki dipakai, kedua elektrodenya perlahan-lahan akan menjadi timbal sulfat. Hal itu disebabkan, kedual elektrode beraksi dengan larutan asam sulfat. Pada reaksi tersebut, elektrode timbal melepaskan banyak elektron [4].

Akibatnya, terjadi aliran arus listrik dari pelat timbal dioksidanya. Setelah beberapa lama dipakai, akhirnya kedua elektrode tertutup oleh timbal sulfat Akibatnya diantara keduanya tidak ada lagi beda potensial. Keadaan tersebut disebut akinya soak/mati. Dalam aki terdapat elemen dan sel untuk penyimpan arus yang mengandung asam sulfat (H2SO4). Tiap sel berisikan pelat positif dan pelat negatif Pada pelat positif terkandung oksid timah coklat ( $\mathrm{Pb}$ 02), sedangkan pelat negative mengandung timah $(\mathrm{Pb})$. Pelat-pelat ditempatkan pada batang penghubung. Pemisah atau separator menjadi isolasi diantara pelat itu, dibuat agar baterai acid mudah beredar disekeliling pelat. Bila ketiga unsur kimia ini berinteraksi, muncullah arus listrik.

Untuk menentukan lamanya pengosongan akumulator yaitu perbandingan antara muatan akumulator dengan arus yang mensupley ke aki dengan persamaan dapat ditulis,

$T=\frac{Q}{I}$

Dimana ,

$\mathrm{T}=$ lamanya (waktu) pengisian akumulator

$\mathrm{Q}=$ kapasitas Akumulator $(\mathrm{AH})$

$\mathrm{I}=$ arus yang di suplay ke aki.

$\mathrm{S}=$ daya semu dalam satuannya (VA).

$\cos \emptyset=$ faktor daya. 


\section{MOTOR AC}

Motor listrik adalah alat untuk mengubah energi listrik menjadi energi mekanik. Motor AC adalah sebuah motor listrik yang di gerakan oleh alternatingcurrent atau arus bolak balik (AC). Umumnya, motor AC terdiri dari dua komponen utama yaitu stator dan rotor. Stator merupakan komponen listrik statis. Rotor merupakan komponen listrik berputar untuk memutar as motor.

Keistimewaan umum dari semua motor AC adalah medan-magnet putar yang diatur dengan lilitan stator. Konsep ini dapat diilustrasikan pada motor tiga-fase dengan mempertimbangkan tiga kumparan yang diletakan bergeser $120^{\circ}$ listrik satu sama lain. Masing-masing kumparn dihubungkan dengan satu fase sumber daya tiga-fase. Apabila arus tiga-fase melalui lilitan tersebut, terjadi pengaruh medan-magnet berputar melalui bagian dalam inti stator. Kecepatn medan-magnet putar tergantung pada jumlah kutub stator dan frekuensi sumber daya [5].

Motor listrik arus bolak-balik AC ini dapat dibedakan lagi berdasarkan sumber dayanya sebagai berikut :

\section{Motor singkron,}

Motor singron adalah motor AC bekerja pada kecepatan tetap pada sistem frekuensi tertentu. Motor ini memerlukan arus searah (DC) untuk pembangkitan daya dan memiliki torque awal yang rendah, dan oleh krena itu motor sinkron cocok untuk penggunaan awal dengan beban rendah, seperti kompresor udara, perubahan frekuensi dan generator motor. Motor singkron mampu untuk memperbaiki factor daya sistem, sehingga sering digunakan pada sistem yang menggunakan banyak listrik.

\section{Motor Induksi}

Motor induksi merupakan motor listrik AC yang bekerja berdasarkan induksi medan magnet antara rotor dan stator. Motor induksi dapat di klasifikasikan menjadi dua kelompok utama sebagai berikut

a. Motor induksi satu fase. Motor ini hanya memiliki satu gulungan stator, beroprasi dengan pasokan daya satu fase, memiliki sebuah rotor kandang tupai, dan memerlukan sebuah alat untuk menghidupkan motornya. Sejauh ini motor ini merupakan jenis motor yang paling umum digunakan dalam peralatan rumah tangga, seperti, mesin cuci, pengering pakaian, dan untuk penggunaan hingga 3 sampai $4 \mathrm{Hp}$.

b. Motor induksi tiga fase. Medan magnet yang berputar dihasilkan oleh pasokan tiga fase yang seimbang. Motor tersebut memiliki kemampuan daya yang tinggi dapat memiliki kandang tupai atau gulungan rotor (walaupun 90\% memiliki rotor kandang tupai) dan penyalaan sendiri. Diperkirakan bahwa sekitar $70 \%$ motor di industri menggunakan jenis ini, sebagai contoh, pompa, kompresor, jaringan listrik, dan grinder. Tersedia dalam ukuran 1/3 hingga ratusan $\mathrm{Hp}$. 


\section{E. Rangkaian Ekivalen Motor AC}

Kerja motor induksi (AC) seperti juga kerja pada transformator. Trasformator adalah berdasarkan prinsip induksi elektromagnetik. Oleh karna itu motor induksi dipandang sebagai trasformator yang mempunyai cirri-ciri khusus, yaitu :

1. Stator sebagai sisi primer.

2. Rotor sebagai sisi sekunder yang penghantar-penghantarnya dihubung singkat dan berputar.

3. Kopling antara sisi primer dan sisi sekunder dipisahkan oleh celah udara (air gap).

Rangkaian ekiavalen pada gambar memperlihatkan bahwadaya keseluruhan yang dialihkan pada celah udara dari stator (masukan daya ke rotor) adalah :

$P_{r}=3 I_{r}^{2} \frac{R r}{S}$.

Rugi tembaga rotor,

$P_{r}=3 I_{r}^{2} R_{r}$

Daya mekanis yang dibangkitkan oleh motor induksi,

$P_{m}=P_{r}-P_{m}=3 I_{r}^{2} \frac{R r}{s}-3 I_{r}^{2} R_{r}=3 I_{r}^{2} R_{r} \frac{(1-s)}{s}$

$P_{m}=T w_{r}=T w_{s}(1-s)$

Dimana:

$\mathrm{T}=$ Torsi Motor dalam N-m

$w_{r}=$ Kecepatan Rotor dalam Rad/detik

$w_{s}=$ Kecepatan Stator dalam Rad/detik

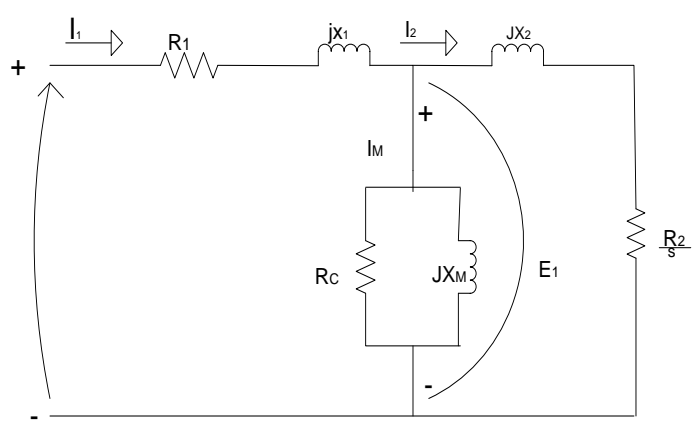

Gambar 2. Rangkaian Ekivalen Motor induksi (AC)

\section{F. Daya Dan Torsi Motor AC}

Motor listik adalah suatu perangkat elektromagnetik yang digunakan untuk, mengkonversi atau mengubah energi listrk menjadi energy mekanik. Namun kita akan membahas tentang menghitung 
arus, daya, pada motor tesebut. Rumus menghitung kecepatan sinkron, jika yang diketahui frekuensi dan jumlah katup pada motor AC. (Dermanto, 2013)

$\mathrm{ns}=\frac{120 . \mathrm{F}}{P}$

Dimana,

$\mathrm{ns}=$ Kecepatan sinkron motor $(\mathrm{rpm})$.

$\mathrm{f}=$ Frekuensi $(\mathrm{Hz})$.

$\mathrm{P}=$ Jumlah Kutub Motor [6].

Menghitung slip pada motor,

$\%$ Slip $=\frac{n s-n}{n s} \times 100$

Dimana:

$\mathrm{n}=$ Kecepatan (rpm)

Menghitung arus/ampere motor ketika diketahui daya (watt), tegangan (volt), dan faktor daya ( $\cos \varphi)$

$\mathrm{P}=\mathrm{V} \cdot \mathrm{I} \cdot \cos \varphi$

$\mathrm{I}=\frac{\mathrm{P}}{V \cdot \cos \varphi}$

Menghitung daya motor 3 phasa ketika diketahui arus, tegangan, dan factor daya.

$\mathrm{P}=\sqrt{3}$. V.I. $\cos \varphi$

$\mathrm{I}=\frac{\mathrm{P}}{\sqrt{3} \cdot \mathrm{V} \cdot \cos \varphi}$

Menghitung daya output motor,

P output $=\sqrt{3}$. V. I. eff. $\cos \varphi$

Menghitung efisiensi daya motor,

$\eta=\frac{\text { P output }}{\mathrm{P}} \times 100 \%$

Menghitung daya semu motor,

Pada motor 1 phasa

S(VA) V. I

Pada motor 3 phasa

$\mathrm{S}=\sqrt{3}$. v. I

\section{METODE PENELITIAN}

\section{A. Diagram fishbone}

Alat aerator bertujuan untuk menghasilkan gelembung-gelembung udara yang kaya oksigen bagi petambak dan penjelasan runtunan penelitian di gambarkan dalam diagram fishbone. 
Dari diagram fishbone 3. studi pengaturan kecepatan motor ac bagi petambak, ada tiga kajian pada diagram tersebut, yaitu: kecepatan motor ac, perakitan alat, pengujian alat.

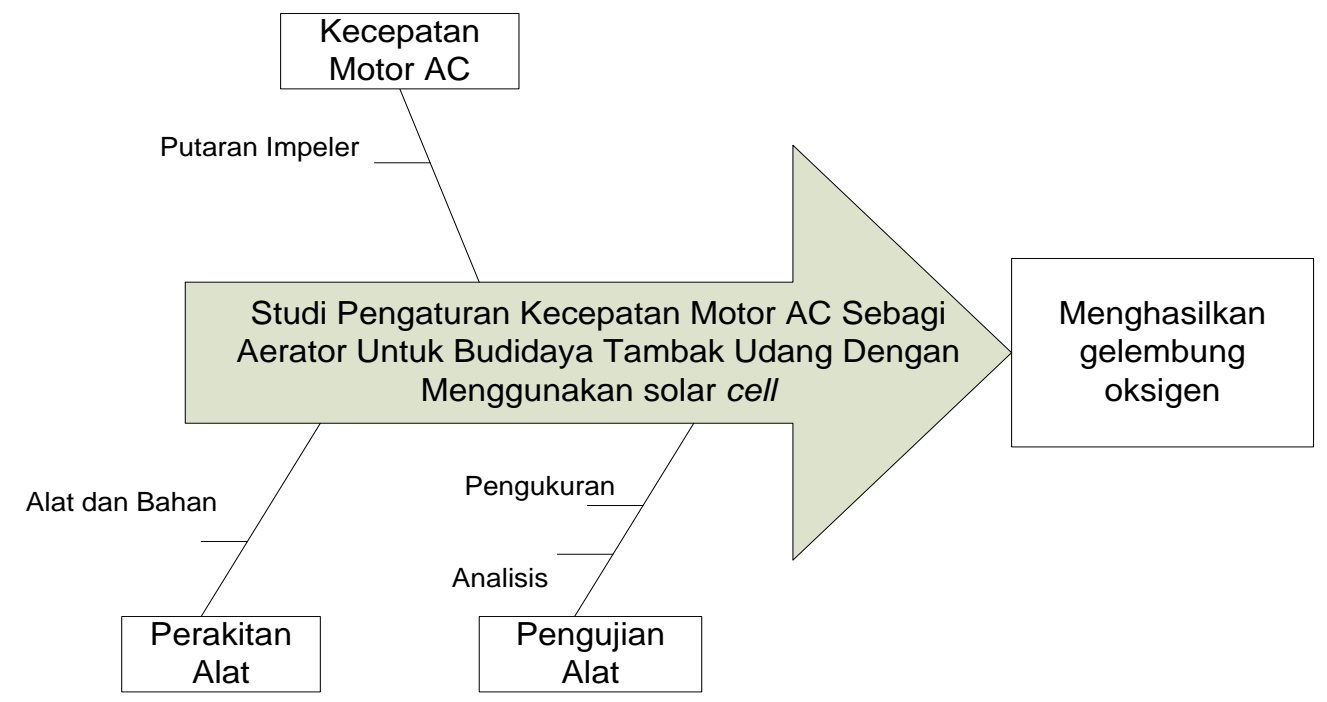

Gambar 3. Diagram fishbone penelitian

\section{B. Diagram Rangkaian}

Dari gambar 3.rangkaian tersebut berfungsi sebagai kendali dari seluruh sistem yang ada untuk penghasil gelembung yang kaya oksigen. Terdiri dari komponen-komponen utama agar dapat berjalan sesuai yang dikehendaki.

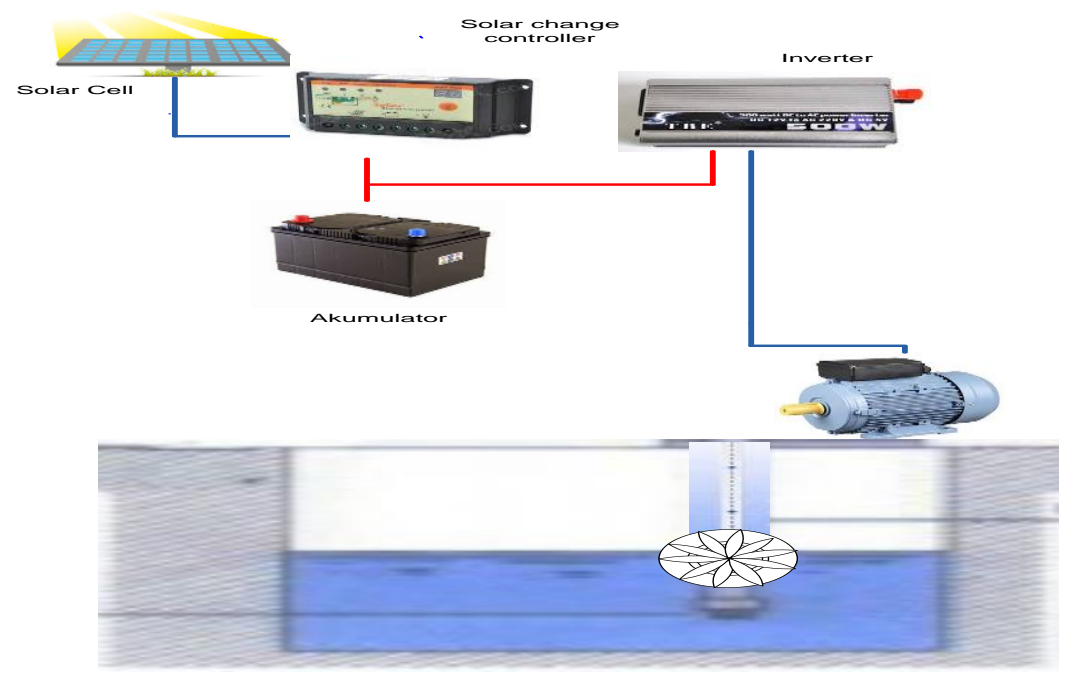

Gambar 3. Rangkaian Arator Tambak udang

\section{Prinsip Kerja Rangkaian}

Mula-mula solar cell menerima dan menyerap matahari, kemudian mengisi muatan arus dan tegangan listriknya ke akumlator 12 volt secara kontinyu. Kemudian dari akumulator arus dan 
tegangan akan disuplay keterminal input inverter, akan mengubah arus searah menjadi arus tengan bolak-balik sebesar 220 volt.

Selanjutnya arus dan tegangan listrik tersebut dialirkan ke alat pengatur kecepatan motor yang bekerja sebagai alat pengatur tegangan listrik ke motor induksi 1 fasa dengan arus dan tegangan inilah, motor induksi berputar dengan kecepatan low rpm-high rpm yaitu 0-1500 rpm. Sehingga rotor motor dengan menggunakan tangkai aerator dapat difungsikan dengan kecepatan putar untuk menjadikan gelembung air dan arus alir airnya.

\section{Diagram Alat Pengatur keceptan motor induksi 1 fasa}

Alat Pengatur kecepatan motor induksi 1 fasa tersebut menggunakan rangkaian tride dan diode dengan system pengatur potensiometer yang bekerja pada tegangan $150 v_{A C}-180 v_{A C}$ dengan daya 1000 watt, alat pengatur sumber listriknya disuplay dari keluaran tegangan inverter $220 v_{A c}$. Frekuensi $50 \mathrm{~Hz}$ dan alat pengatur tersebut tidak menimbulkan panas ketika motor akan diatur kecepatan putar nya dari kecepatan rendah sampai dengan kecepatan yang dikehendaki. Adapun rangkaian diagram dapat dilihat pada gambar 4. dibawah.

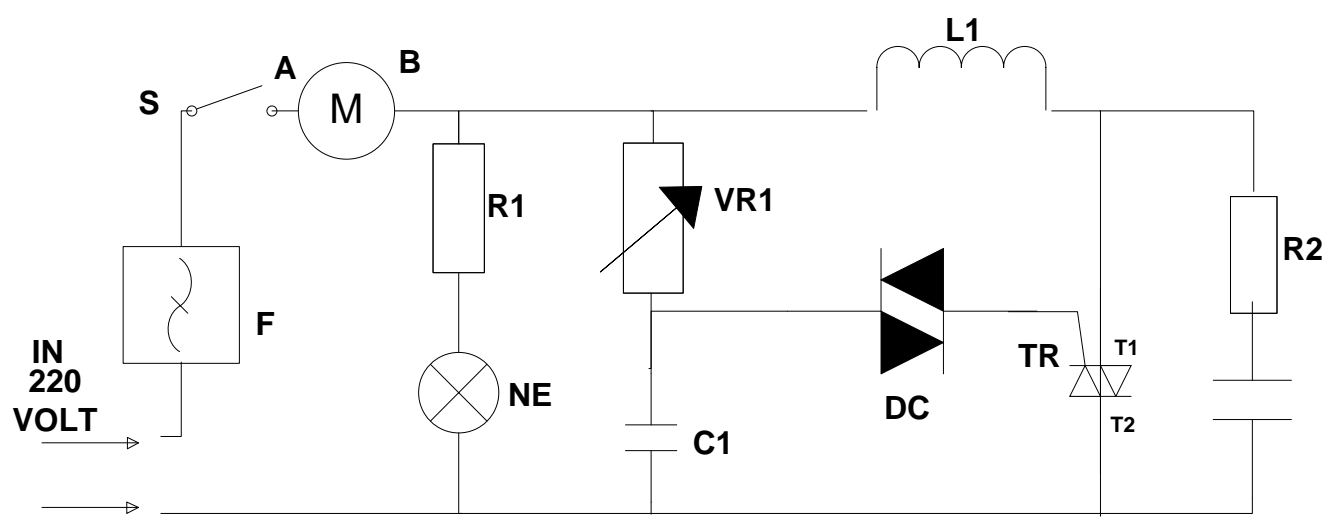

Gambar 4.Diagram Rangkaian Alat Pengatur Kecepatan Motor 1 fasa

Keterangan:

1. $v_{A c}=$ Tegangan Input $220 \mathrm{~V}$

2. $\mu=$ Motor Induksi 1 fasa

3. $\mathrm{S}=$ Suit on/off $5 \mathrm{~A}-220 \mathrm{~V}$

4. $R_{1}=100 \mathrm{~K}^{\prime} \Omega / 1 / 2$ watt

5. $R_{2}=100 ' \Omega / 5$ watt

6. $c_{1}=0,1 \mu f / 450 \mathrm{~V}$

7. $c_{2}=0,22 \mu f / 450 \mathrm{~V}$

8. $v_{R}=$ Variabel Resistan $250 \mathrm{k} ' \Omega / 2$ watt

9. $D_{c}=\mathrm{Diac} \mathrm{qv} / 1$ ampere

10. $T R=$ Tride 10 Ampere $/ 450 \mathrm{~V}$ 


\section{E. Prinsip Kerja Rangkaian}

Ketika tegangan masuk ke $\mathrm{F}_{1}$ dan $\mathrm{S}_{1}$ dalam keadaan on, maka arus mengalir ke motor terminal A kemudian arus yang keluar dari motor terminal B mengalir ke variabel resistor, diae, ke gate triae, kemudian arus pun mengalir ke triae di bagian terminal $\mathrm{T}_{1}$ kemudian ke $\mathrm{T}_{2}$, yang aru puncaknya di filter oleh $R_{2}$ dan $c_{2}$ pada kedudukan $v_{R 1}$, resistansi rendah motor berputar pada kondisi lambat dan variable resistansi diputar ke resisansi tinggi, motor berputar pada kecepatan maksimum dan aerator pun berputar sesuai dengan kecepatan motor yang di atur.

\section{ANALISA DAN PEMBAHASAN}

\section{A. Data Inverter}

Data inverter untuk sumber energi alat penggerak aerator berupa motor induksi 1 fasa dengan kecepatan start kapasitor, dari gerak mekanik motor inilah kipas aerator dapat bekerja dengan kecepatan yang dapat di atur mulai dari kecepatan rendah sampai dengan kecepatan tinggi, adapun inverter yang digunakan karakteristiknya dapat dilihat pada tabel.1 dibawah ini.

Tabel 1 Data Inverter

\begin{tabular}{|c|c|c|}
\hline $\mathrm{NO}$ & Inverter & Kapasitas \\
\hline 1 & Tegangan Input & $12 \mathrm{~V}_{\mathrm{ac}}$ \\
\hline 2 & Tegangan Output & $220 V_{a c}$ \\
\hline 3 & Frekuensi & $50 \mathrm{H}_{\mathrm{z}}$ \\
\hline 4 & Faktor Daya & $\operatorname{Cos} \varphi=0,90$ \\
\hline 5 & Daya Penguat & 1000 Watt \\
\hline 6 & Transformator Motor Induksi & $12 \mathrm{~V}_{\mathrm{ac}}-\mathrm{cf}-12 \mathrm{~V}_{\mathrm{ac}}$ \\
\hline 7 & Penguat Inverter & Jenis Mosfet \\
\hline 8 & Akumulator & $12 \mathrm{v} / 70 \mathrm{AH}$ \\
\hline 9 & Daya Inverter & $500 \mathrm{w}$ \\
\hline
\end{tabular}

\section{B. Data Solar cell}

Pada penelitian ini sumber pengerak aerator pada tambak menggunakan sumber energiSolar cell dan sekaligus berfungsi sebagai alat pengisi muatan listrik pada akumulator, yang mana sumber energi tersebut sangat murah dan ramah lingkungan.dan bisa didapatkan selama matahari bersinar secara efektif dari jam 09:00 sampai 03:00 pun kecepatan pengisian dan arus tegangan akumulator dilengkapi dengan sistem control charger otomatis yang data tabelnya dapat dilihat pada tabel 2 dibawah ini.

Tabel 2 Data Solar Cell dan changer

\begin{tabular}{cll}
\hline No & Solar cell dan change & \multicolumn{1}{c}{ Kapasitas } \\
\hline 1 & Daya Solar Cell & $100 \mathrm{~W}$ \\
2 & Tegangan Kerja & 17,5 Volt \\
3 & Tegangan Terbuka & 21,5 volt \\
4 & Arus Normal & 5,7 Ampere \\
5 & Arus Hubung Singkat & 7,02 Ampere \\
6 & Temperatur & $25^{\circ} \mathrm{C}-38^{\circ} \mathrm{C}$ \\
7 & Tegangan Regulator Solar Cell Input & $17 \mathrm{~V}$ \\
8 & Tegangan Keluaran Solar Cell & $13,8 \mathrm{~V}-14,5 \mathrm{~V}$ \\
9 & Arus Keluaran & Max 20 ampere \\
10 & Sistem Kerja & Otomatis \\
\hline
\end{tabular}




\section{Data Motor dan Alat Pengatur Kecepatan}

Motor yang dipakai dalam penggerak aerator tersebut motor induksi 1 fasa dengan sumber listriknya diatur dari sumber listrik keluaran inverter, yang mana proses pengaturan kecepatanya menggunakan sistem triac. Data motor dan alat pengatur kecepatan, Dapat dilihat pada tabel 4.3 dibawah ini.

Tabel 3 Data Motor Dan Alat Pengatur Kecepatan

\begin{tabular}{cll}
\hline No & \multicolumn{1}{c}{ Motor Dan Alat Pengatur } & \multicolumn{1}{c}{ Kapasitas } \\
\hline 1 & Jenis Motor & Induksi 1 fasa, Start kapasitor \\
2 & $V_{\text {in }}$ & $220 V_{A C}$ \\
3 & Frekuensi & $50 H_{Z}$ \\
4 & Arus Maximum & 0,70 Ampere \\
5 & Jenis Kutub & 4 Buah \\
6 & Kapasitor & $5 \mu f$ / 450 V \\
7 & Alat Pengatur & Jenis Triac \\
8 & Tegangan Input & $13 \mathrm{~V}_{\mathrm{AC}}-220 \mathrm{~V}_{\mathrm{AC}}$ \\
9 & Tegangan Autput & $0-220 V_{A C}$ \\
10 & Daya Alat Pengatur & 1000 watt \\
\hline
\end{tabular}

\section{Data Hasil Pengukuran}

Pertama Motor yang akan diuji coba terlebih dahulu harus disiapkan peralatannya yaitu seperti akumulator, inverter, alat pengatur kecepatan putar. Langkah awal pengujian koneksikan lebih dahulu motor pada alat pengatur kecepatan putar, langkah awal pengujinyaitu koneksikanterlebih dahulu motor pada alat pengatur kecepatan kemudiaan alat tersebut dikoneksi ke sumber tegangan keluaran inverter. Dengan menghidupkan inverter motor diatur putarannya dengan menggunakan alat pengatur.

Selanjutnya ukur arus dan tegangan input dan autput inverter dan ukur pula kcepatan putar rotor, menggunakan tekno meter ukur juga arusnya menggunakan tang ampere dan pengukuran tegangan nya memakai volt meter. Pengujian motor tersebut tanpa dengan menggunakan stik aerator. dari hasil pengukuran motor tersebut dapat dilihat pada tabel dibawah ini.

Tabel 4. Data Pengukuran Motor Tanpa Beban

\begin{tabular}{ccccccc}
\hline No & $\begin{array}{c}\mathrm{V}_{\text {in }} \text { (inv) } \\
(\mathrm{v})\end{array}$ & $\begin{array}{c}\mathrm{I}_{\text {in }} \text { (inv) } \\
(\mathrm{A})\end{array}$ & $\begin{array}{c}\mathrm{V}_{\text {out }}(\text { inv }) \\
(\mathrm{v})\end{array}$ & $\begin{array}{c}\mathrm{I}_{\text {out }}(\text { inv }) \\
(\mathrm{A})\end{array}$ & Rpm & Kecepatan \\
\hline 1 & 13,2 & 3,5 & 185 & 0,25 & 900 & \\
2 & 12,8 & 4,1 & 180 & 0,3 & 1110 & Rendah \\
3 & 12,4 & 4,8 & 178 & 0,38 & 1440 & Tinggi \\
\hline
\end{tabular}

Tabel 5. Data Pengukuran Motor Berbeban

\begin{tabular}{ccccccc}
\hline No & $\begin{array}{c}\mathrm{V}_{\text {in }} \text { (inv) } \\
(\mathrm{v})\end{array}$ & $\begin{array}{c}\mathrm{I}_{\text {in }} \text { (inv) } \\
(\mathrm{A})\end{array}$ & $\begin{array}{c}\mathrm{V}_{\text {out }} \text { (inv) } \\
(\mathrm{v})\end{array}$ & $\begin{array}{c}\mathrm{I}_{\text {out }}(\text { inv }) \\
(\mathrm{A})\end{array}$ & Rpm & Kecepatan \\
\hline 1 & 12,8 & 7,5 & 185 & 0,37 & 750 & Rendah \\
2 & 12,4 & 8,7 & 179 & 0,45 & 800 & Sedang \\
3 & 12,1 & 11,6 & 175 & 0,6 & 1125 & Tinggi \\
\hline
\end{tabular}




\section{E. Analisa Perhitungan kecepatan motor}

Untuk Perhitungan Data pengujian kecepatan motor tanpa beban dari tabel 4.4. adalah sebagai berikut:

Daya pada input motor

- Kecepatan Rendah

$$
\begin{aligned}
P_{i n_{1}} & =v_{i n(i n v) \times I_{i n \times \cos \varphi}} \\
& =13,2 \times 3,5 \times 0,9 \\
& =41.58 \text { watt } \\
& - \text { Kecepatan Sedang } \\
P_{i n_{2}} & =v_{\text {in }(i n v) \times I_{\text {in } \times \cos \varphi}} \\
& =12,8 \times 4,1 \times 0,9 \\
& =47,23 \text { watt } \\
& - \text { Kecepatan Tinggi } \\
P_{i n_{3}} & \left.=v_{\text {in }} \text { inv }\right) \times I_{i n} \times \cos \varphi \\
& =12,4 \times 4,8 \times 0,9 \\
& =53,56 \text { watt }
\end{aligned}
$$

Daya pada output tanpa beban

- Kecepatan Rendah

$$
\begin{aligned}
& P_{\text {out }_{1}}=v_{\text {out }}(\text { inv }) \times I_{\text {out }} \times \cos \varphi \\
&=185 \times 0,25 \times 0,9 \\
&=41,62 \text { watt } \\
& \text { - } \text { Kecepatan Sedang } \\
& P_{\text {out }_{2}}=v_{\text {out }}(\text { inv }) \times I_{\text {out }} \times \cos \varphi \\
&=180 \times 0,3 \times 0,9 \\
&=48,6 \text { watt } \\
&- \text { Kecepatan Tinggi } \\
& P_{\text {out }_{3}}=v_{\text {out }}(\text { inv }) \times I_{\text {out }} \times \cos \varphi \\
&= 178 \times 0,38 \times 0,9 \\
& 60,87 \text { watt }
\end{aligned}
$$

Untuk Pehitungan data pengujian motor berbeban dari tabel 4.5. adalah sebagai berikut :

- Daya output berbeban

$$
\begin{gathered}
P_{\text {out }_{1}}=v_{\text {out }}(\text { inv }) \times I_{\text {out }} \times \cos \varphi \\
=185 \times 0,37 \times 0,9
\end{gathered}
$$




$$
\begin{aligned}
& =61,60 \text { watt } \\
\bullet & \text { Kecepatan Sedang } \\
P_{\text {out }_{2}} & =v_{\text {out }(\text { inv }) \times I_{\text {out }} \times \cos \varphi} \\
& =179 \times 0,45 \times 0,9 \\
& =72,49 \mathrm{watt} \\
& \bullet \text { Kecepatan Tinggi } \\
P_{\text {out }_{3}} & \left.=v_{\text {out }} \text { (inv }\right) \times I_{\text {out }} \times \cos \varphi \\
& =175 \times 0,6 \times 0,9 \\
& =94,5 \text { watt }
\end{aligned}
$$

Daya input berbeban

- Kecepatan Rendah

$$
\begin{aligned}
P_{i n_{1}} & =v_{i n(i n v) \times I_{i n \times \cos \varphi}} \\
& =12,8 \times 7,5 \times 0,9 \\
& =86,4 \text { watt } \\
& \bullet \text { Kecepatan Sedang } \\
P_{i n_{2}} & =v_{\text {in }}(\text { inv }) \times I_{i n \times \cos \varphi} \\
& =12,4 \times 8,7 \times 0,9 \\
& =97,09 \text { watt } \\
& \bullet \text { Kecepatan Tinggi } \\
P_{i n_{3}} & =v_{i n}(\text { inv }) \times I_{i n \times \cos \varphi} \\
& =12,1 \times 11,6 \times 0,9 \\
& =126,32 \mathrm{watt}
\end{aligned}
$$

\section{KESIMPULAN}

1. Perbedaan kecepatan motor pada saat kecepatan rendah, sedang, tinggi didapatkan daya masing-masing dengan nilai yang tidak jauh berbeda. Kecepatan rendah 46,2 watt, sedang 52,48 watt, tinggi 59.52 watt.

2. Terdapat perbedaan waktu pengosongan akumulator pada saat inverter menggunakan sumber solar cell dengan nilai waktu $T_{1}(1,6 \mathrm{jam}), T_{2}(12,2 \mathrm{jam}), T_{3}(10,6 \mathrm{jam}), T_{4}(5,4)$ dan $T_{5}(6,8$ jam).

\section{DAFTAR PUSTAKA}

[1] Fany, A. (2010). Indonesia, Negara Kepulauan Terbesar di Dunia. Dipetik 7 9, 2018, dari 
https://ahmadfany.wordpress.com/2010/09/15/indonesia-negara-kepulauan-terbesardi\%C2\%A0dunia/

[2] Putra, Y. M. (2014). Udang Jadi Andalan Ekspor Perikanan Indonesia. Retrieved 7 9, 2018, from

https://www.republika.co.id/berita/ekonomi/bisnis/14/04/02/n3eh3y-udang-jadi-andalanekspor-perikanan-indonesia

[3] Supriyadi, Z., Wibowo, A., \& Farid, A. (2015). Peningkatan Kinerja Aerator Tambak. 11 (2), $65-68$.

[5] Indriana, T. (2014). Akumulator. Retrieved 6 24, 2018, from http://tania210998.blogspot.com/2014/09/akumulator.html

[5] Wibowo, P., Kartoraharjo, S., Agustina, Y., \& Wachyu, Y. (2012). Motor Penggerak Listrik.

[6] Dermanto, T. (2013). arus, Daya, Kecepatan, dan Torsi Motor Listrik AC. Dipetik 624 , 2018, from http://trikueni-desain- sistem.blogspot.com/2013/09/Menghitung-Arus-MotorAC.html 